\title{
ANALISIS ZAT GIZI DAN ORGANOLEPTIK OLAHAN SOSIS IKAN GABUS SEBAGAI PANGAN ALTERNATIF MENCEGAH STUNTING
}

\author{
Chaerunnimah, Aswita Amir, Retno Sri Lestari, Adriyani Adam ${ }^{\bowtie}$ \\ Jurusan Gizi Poltekkes Kemenkes Makassar
}

\begin{tabular}{l} 
ARTICLE INFO \\
\hline Article history \\
Submitted : 2021-11-28 \\
Revised : 2021-12-04 \\
Accepted : 2021-12-30 \\
Keywords: \\
Cork fish sausage \\
Nutrition \\
Organoleptik
\end{tabular}

Kata Kunci:

Sosis ikan gabus

Gizi

Organoleptik

\begin{abstract}
The prevalence of stunting in Indonesia is still high at $30,8 \%$. Low protein intake is one of the causes of stunting. The purpose of this study was to determine the nutritional analysis and organoleptic quality in cork fish sausages. This study used a completely randomized design with 3 repetitions. Nutrient analysis was obtained from the Luff schroll test for carbohydrates, fat test with shoxlet and protein test with micro kjedhall. Organoleptic quality with acceptance of taste, texture, color and aroma by descriptive. Research results with univariate analisis were the highest nutrient content of protein and carbohydrate in formula F1 $(100 \%)$ is protein $(16.71 \%)$ and carbohydrate $(20.14 \%)$ and the highest fat content in formula F3 (60\%) is as much as $(18.52 \%)$. The most preferred organoleptic quality for aroma and taste is in formula F1 (100\%), texture is in formula F2(80\%) and the most preferred color is in formula F3 (60\%). The recommendation for prevent stunting can be used F1 formula.

Prevalensi stunting di Indonesia masih tinggi yaitu 30,8\%. Asupan protein yang rendah merupakan salah satu penyebab terjadinya stunting. Tujuan penelitian ini untuk mengetahui analisa zat gizi dan mutu organoleptik pada sosis ikan gabus. Penelitian ini menggunakan metode Rancangan Acak Lengkap dengan 3 kali pengulangan. Analisis zat gizi diperoleh dari hasil uji Luff schroll untuk karbohidrat, uji lemak dengan shoxlet dan uji protein dengan micro kjedhall. Mutu organoleptik dengan uji daya terima rasa, tekstur, warna dan aroma secara deskriptif. Adapun hasil univariat penelitian ini adalah kandungan nilai gizi protein dan karbohidrat paling tinggi pada formula F1 (100\%) yaitu protein $(16,71 \%)$ dan karbohidrat $(20,14 \%)$ dan pada kandungan lemak tertinggi pada formula $\mathrm{F} 3(60 \%)$ sebanyak $(18,52 \%)$. Mutu organoleptik yang paling disukai untuk aroma dan rasa yaitu pada formula F1 (100\%), tekstur pada formula F2 (80\%) dan warna yang paling disukai yaitu pada formula F3 (60\%). Rekomendasi formula F1 dapat dimanfaatkan untuk pencegahan stunting.
\end{abstract}

Corresponding Author:

\author{
Adriyani Adam \\ Jurusan Gizi Poltekkes Kemenkes Makassar \\ Telp. 0811415843 \\ Email: pinkymkes@gmail.com
}

\section{PENDAHULUAN}

Prevalensi balita stunting berdasarkan data Riset Kesehatan Dasar (Riskesdas) tahun 2018 menunjukkan prevalensi balita yang stunting di Indonesia masih tinggi yaitu 30,8\%. Sedangkan prevalensi balita stunting untuk wilayah Sulawesi Selatan juga masih cukup tinggi yaitu $35,4 \%$. Besarnya angka kejadian masalah gizi pada balita menunjukkan bahwa penanganan masalah ini belum optimal (Badan Penelitian Pengembangan Kesehatan, 2018).

Stunting dapat menyebabkan gangguan perkembangan fisik, Intelligence Quotient (IQ) sebelas poin lebih rendah dibandingkan dengan anak normal dengan umur yang sama. Kekurangan gizi yang tidak diatasi sejak dini akan berdampak pada perkembangan dan pertumbuhannya sampai usia dewasa (Marimbi, 2014). Stunting dapat disebabkan oleh beberapa faktor antara lain adalah makanan yang tidak memenuhi kebutuhan terutama pada masa pertumbuhan. Asupan protein yang tidak mencukupi merupakan penyumbang terhadap kejadian stunting.

Sumber protein yang dikenal oleh berbagai lapisan masyarakat dan dunia adalah ikan. Ikan di Indonesia merupakan sumber protein yang baik dan cukup mudah diperoleh. Sumber protein dari hewani yang lain seperti daging dan ayam harganya cukup mahal. Mahalnya harga bahan pangan ini diikuti 
dengan tingginya kejadian stunting di Indonesia (Sunita, Almatsier, Susirah Soetardjo, 2011). Indonesia kaya dengan hasil laut terutama ikan. Namun demikian asupan protein nabati tertinggi sebanyak $68.3 \%$, sedangkan protein hewani baru mencapai $31.7 \%$. Hal ini berdampak pada pertumbuhan balita, bioavabilitas produk hewani lebih tingi dari pada nabati. Protein hewani jauh lebih baik dalam menunjang pertumbuhan balita terutama ikan merupakan sumber protein dengan kualitas tertinggi. Asam amino lysine yang terkandung dalam ikan memiliki biovailabilitas tinggi, kandungan omega-3 seperti DHA dan EFA merupakan unsur zat gizi yang dapat meningkatkan fungsi saraf dan otak balita sehingga ikan dapat dinyatakan berkontribusi untuk kecerdasan bangsa dimasa yang akan datang (WHO, 2005).

Selain sebagai sumber protein, ikan juga sebagai sumber lemak, vitamin, dan mineral yang sangat baik. Data Susenas BPS menunjukkan bahwa sumbangan protein ikan terhadap konsumsi protein hewani masyarakat Indonesia mencapai 57\% (Saefuddin, 2015). Ikan sebagai sumber protein yang baik karena kuantitasnya yang mengandung protein sekitar 15-24\% dan kelengkapan asam amino serta tingkat kecernaannya yang mencapai $95 \%$ (Rahayu, 2008)

Penyelesaian masalah gizi pada balita yang tidak kunjung berakhir menyebabkan perlunya mencari alternatif sumber protein yang murah dan mudah didapat. Kota Makassar merupakan kota dengan hasil ikan yang melimpah. Hasil ikan yang melimpah merupakan potensi wilayah yang dapat ditarik manfaat lebih besar sebagai penyedia protein ikan yang baik. Peningkatan konsumsi ikan pada anak balita bukan masalah yang mudah, diperlukan kreativitas dalam pengolahannya mengingat balita merupakan konsumen pasif dan aktif dengan karakteristik pemilihan makanan yang sangat subjektif.

Alternatif sumber protein hewani yang tepat untuk anak balita saat ini dan memungkinkan untuk dikembangkan adalah sosis ikan. Sosis ikan merupakan makanan olahan berbasis ikan dengan teknik pengolahan ikan yang relatif sederhana, murah, tidak membutuhkan bahan-bahan kimia tambahan dan mudah dilakukan oleh rumah tangga. Sosis ikan juga merupakan jenis makanan yang sudah umum. Namun demikian sosis ikan selama ini lebih dikenal sebagai produk pangan untuk kalangan menengah ke atas sehingga nilai jual sosis ikan sangat tinggi.

Bahan utama sosis umumnya terbuat dari daging sapi, ayam dan babi. Sosis juga dapat dibuat dari ikan dengan kualitas yang baik dan kandungan lemak dari ikan lebih rendah dari daging sapi (Abrori, F, 2003). Sosis merupakan campuran daging yang dihaluskan dengan rempah dan dimasukkan dalam selongsong pembungkus khusus yang kemudian dimasak atau dikukus (Koapaha, 2009).

Tujuan umum pada penelitian ini adalah mengolah sosis dari ikan gabus (Channa striata) sebagai pangan alternatif pencegahan stunting. Tujuan khusus adalah menganalisis kandungan zat gizi pada hasil olahan sosis ikan gabus (Channa Striata) dan menganalisis mutu organoleptik pada hasil olahan sosis ikan gabus (Channa Striata).

\section{METODE PENELITIAN \\ Jenis Penelitian}

Penelitian ini merupakan penelitian eksperimental yaitu pembuatan sosis ikan gabus dengan menilai kandungan zat gizi dan mutu organoleptik. Desain penelitian yang digunakanadalahpost test group design. Jenis penelitian yang digunakan adalah analitik dengan desain cross sectional.

\section{Lokasi dan Waktu Penelitian}

Tempat penelitian dilakukan di Laboratorium Teknologi Pangan Jurusan Gizi Politeknik Kesehatan Makassar. Pelaksanaannya dilakukan pada bulan Maret - Oktober 2019.

\section{Sampel Penelitian}

Sampel penelitian yaitu sosis yang terbuat dari ikan gabus. Sosis ikan gabus ini dibuat dalam 3 formula dengan uji kandungan zat gizi sebanyak 3 kali pengulangan. Formula F1(100 $\% \mathrm{t})$ terdiri dari 100 gram ikan gabus, Formula F2(80\%) terdiri dari 80 gram ikan gabus dan 20 gram wortel. Formula F3 (60\%) terdiri dari 60 gram ikan gabus dan 40 gram wortel.

\section{Pengumpulan Data}

Jenis data analisis nilai gizi dan mutu organoleptik sosis ikan gabus (Channa Striata) yang diperoleh dalam penelitian ini adalah data primer berdasarkan uji laboratorium kandungan zat gizi sosis dan uji organoleptik. Cara 
pengumpulan data kandungan zat gizi diperoleh dari hasil uji Luff Schroll, Shoxlet, dan Micro Kjedhall.

Mutu organoleptik diperoleh dengan melakukan uji hedonik menggunakan panelis yang tidak terlatih (30 orang). Uji organoleptik pada penelitian ini dikategorikan pada uji sifat uji organoleptik yang meliputi penilaian rasa, warna, aroma, dan tekstur.

\section{Pengolahan dan Analisis Data}

Analisis data hasil penelitian dilakukan dengan cara deskriptif dengan menggunakan perangkat komputer. Data univariat dideskripsikan dan dipersentase berdasarkan variabel penelitian. Data disajikan dalam bentuk narasi dan distribusi nilai rata-rata. Kesimpulan dari penilaian mutu organoleptik meliputi warna, rasa, aroma dan tekstur dilakukan dengan menggunakan uji daya terima. Adapun Ethical Approval penelitian ini dari Komisi Etik Poltekkes Kemenkes Makassar.

\section{HASIL PENELITIAN}

Analisis yang dilakukan di laboratorium terhadap uji kandungan zat gizi makro didapatkan hasil sebagai berikut F1(100\%) nilai kandungan proteinnya 16,71 gram, lemak 6,67 gram dan karbohidrat 20,14 gram. Formula F2 (80\%) kandungan proteinnya 15,66 gram, lemak 10,96 gram dan karbohidrat 19,64 gram. Formula F3 (60\%) kandungan proteinnya 13,25 gram, lemak 14,51 gram dan karbohidrat 18,52 gram.

Tabel 1. Kandungan Zat Gizi pada Sosis Ikan Gabus

\begin{tabular}{cccc}
\hline Jenis Analisis & \multicolumn{3}{c}{ Hasil Analisis (\%) } \\
\hline & $\mathrm{F} 1(100 \%)$ & $\mathrm{F} 2(80 \%)$ & $\mathrm{F} 3(60 \%)$ \\
\hline Protein & 16,71 & 15,66 & 13,25 \\
Lemak & 6,61 & 10,96 & 14,51 \\
Karbohidrat & 20,14 & 19,64 & 18,52 \\
\hline
\end{tabular}

Mutu organoleptik pada sosis ikan gabus dilakukan melalui uji daya terima dengan menggunakan panelis sebanyak 30 orang. Uji daya terima dilakukan di Laboratorium Daya Terima di Jurusan Gizi Poltekkes Kemenkes
Makassar. Mutu organoleptik yang paling disukai untuk aroma dan rasa yaitu pada formula F1 (100\%), tekstur pada formula F2 $(80 \%)$ dan warna yang paling disukai yaitu pada formula $\mathrm{F} 3(60 \%)$.

Tabel 2. Hasil Organoleptik pada Sosis Ikan Gabus

\begin{tabular}{|c|c|c|c|c|c|c|c|c|c|c|c|c|}
\hline \multirow{2}{*}{$\begin{array}{c}\text { Tk. } \\
\text { Kesukaan }\end{array}$} & \multicolumn{3}{|c|}{ Rasa } & \multicolumn{3}{|c|}{ Aroma } & \multicolumn{3}{|c|}{ Tekstur } & \multicolumn{3}{|c|}{ Warna } \\
\hline & F1 & F2 & F3 & F1 & F2 & F3 & F1 & F2 & F3 & F1 & F2 & F3 \\
\hline Sangat Suka & $\begin{array}{c}14 \\
(46 \%)\end{array}$ & $\begin{array}{c}9 \\
(30 \%)\end{array}$ & $\begin{array}{c}6 \\
(20 \%)\end{array}$ & $\begin{array}{c}16 \\
(53 \%)\end{array}$ & $\begin{array}{c}11 \\
(36 \%)\end{array}$ & $\begin{array}{c}7 \\
(23 \%)\end{array}$ & $\begin{array}{c}5 \\
(16 \%)\end{array}$ & $\begin{array}{c}8 \\
(26 \%)\end{array}$ & $\begin{array}{c}5 \\
(16 \%)\end{array}$ & $\begin{array}{c}2 \\
(6 \%)\end{array}$ & $\begin{array}{c}6 \\
(20 \%)\end{array}$ & $\begin{array}{c}11 \\
(36 \%)\end{array}$ \\
\hline Suka & $\begin{array}{c}13 \\
(43 \%)\end{array}$ & $\begin{array}{c}13 \\
(43 \%)\end{array}$ & $\begin{array}{c}13 \\
(43 \%)\end{array}$ & $\begin{array}{c}14 \\
(46 \%)\end{array}$ & $\begin{array}{c}15 \\
(50 \%)\end{array}$ & $\begin{array}{c}15 \\
(50 \%)\end{array}$ & $\begin{array}{c}15 \\
(50 \%)\end{array}$ & $\begin{array}{c}9 \\
(30 \%)\end{array}$ & $\begin{array}{c}12 \\
(40 \%)\end{array}$ & $\begin{array}{c}22 \\
(73)\end{array}$ & $\begin{array}{c}22 \\
(73 \%)\end{array}$ & $\begin{array}{c}15 \\
(50 \%)\end{array}$ \\
\hline Tidak Suka & $\begin{array}{c}3 \\
(10 \%)\end{array}$ & $\begin{array}{c}8 \\
(26 \%)\end{array}$ & $\begin{array}{c}9 \\
(30 \%)\end{array}$ & 0 & $\begin{array}{c}4 \\
(13 \% 0\end{array}$ & $\begin{array}{c}8 \\
(26 \%)\end{array}$ & $\begin{array}{c}10 \\
(33 \%)\end{array}$ & $\begin{array}{c}13 \\
(43 \%)\end{array}$ & $\begin{array}{c}13 \\
(43 \%)\end{array}$ & $\begin{array}{c}6 \\
(20 \%)\end{array}$ & $\begin{array}{c}2 \\
(6 \%)\end{array}$ & $\begin{array}{c}4 \\
(13 \%)\end{array}$ \\
\hline $\begin{array}{c}\text { Sangat Tidak } \\
\text { Suka }\end{array}$ & 0 & 0 & $\begin{array}{c}2 \\
(6 \%)\end{array}$ & 0 & 0 & 0 & 0 & 0 & 0 & 0 & 0 & 0 \\
\hline Total & 30 & 30 & 30 & 30 & 30 & 30 & 30 & 30 & 30 & 30 & 30 & 30 \\
\hline
\end{tabular}

\section{PEMBAHASAN}

Kandungan nilai protein dan karbohidrat yang tinggi pada sosis formula F1 $(100 \%)$ sangat cocok untuk pangan alternatif untuk balita sebagai pangan alternatif pencegahan stunting. Sosis ikan gabus ini mengandung nilai gizi yang cukup untuk memenuhi kebutuhan zat gizi balita.

Protein merupakan faktor penunjang pertumbuhan yang sangat penting. Hasil penelitian yang dilakukan olah Rachimi dan 
Partiwi menyebutkan bahwa ada pengaruh asupan protein dan kejadian stunting (Pratiwi, 2017). Protein sebagai zat pembangun berfungsi sebagai pembentuk jaringan yang baru dalam tubuh. Jika kebutuhan energi di dalam tubuh tidak tercukupi maka protein akan mengambil alih fungsi sebagai sumber karbohidrat. Hal ini akan akan mengganggu fungsi protein. Pertumbuhan tidak akan berjalan dengan baik terutama pada masa balita. Pemenuhan energi dan protein pada masa pertumbuhan adalah pendukung utama dalam tumbuh kembang anak (Rosalinda Gibson, 2006).

Selama kehamilan, bayi sampai usia dua tahun adalah masa penting untuk pemenuhan gizi. Semua zat gizi penting untuk pertumbuhan dan perkembangan, terutama protein, dan mikronutrien antara lain zink, yodium, zat besi, vitamin $\mathrm{A}$, vitamin $\mathrm{D}$, vitamin B12, asam folat. Kebutuhan energi harus tercukupi agar protein tidak dimanfaatkan sebagai sumber energi oleh tubuh dan bisa digunakan untuk pertumbuhan (Rosalinda Gibson, 2006).

Kandungan nilai gizi yang cukup tinggi pada sosi ikan gabus bisa menjadi alternatif untuk pemenuhan gizi pada balita. Pemberian ikan pada balita menjadi sangat penting karena kandungan ikan yang merupakan sumber protein sangat dibutuhkan oleh balita pada masa pertumbuhannya. Pemenuhan zat gizi yang cukup pada balita pada masa pertumbuhannya merupakan langkah awal pencegahan stunting. Pemberian ikan pada balita sering menjadi penolakan, karena aroma dan bau khas pada ikan yang pada beberapa balita tidak menyukai. Sosis ikan gabus bisa menjadi alternatif pengganti pangan untuk memenuhi kebutuhan protein dan lemak pada balita.

Setelah melakukan uji daya terima terhadap mutu organoleptik sosis ikan gabus didapatkan hasil bahwa rasa yang paling disukai atau sangat suka dari sosis ikan gabus formula F1 (100\%) sebanyak 14 orang (46\%). Begitu pula dengan aroma, sosis ikan gabus yang paling banyak disukai/sangat suka yaitu pada sosis ikan gabus formula F1 (100\%) sebanyak 16 orang $(53 \%)$.

Sosis ikan gabus yang disukai adalah pada formula F1Sosis ikan gabus formula F1 (100\%) ini menggunakan bahan ikan gabus $100 \%$ tanpa ada tambahan lain. Rasa dan aroma paling disukai karena hanya menonjolkan rasa ikan gabus ditambah dengan bumbu dasar lainnya. Rasa dan tekstur sosis buatan pabrik yang beredar di pasaran adalah sosis yang bertekstur sangat halus dan tanpa aroma atau bau dari daging atau ikan sehingga disukai oleh konsumen.

Mutu organoleptik sosis ikan gabus pada tekstur sebanyak 8 orang (26\%) menyatakan sangat suka dengan sosis ikan gabus formula F2(80\%). Pada formula F2 $(80 \%)$ ikan gabus yang digunakan sebanyak $80 \%$ dan $20 \%$ lainnya adalah wortel. Sedangkan untuk formula F3(60\%) menggunakan daging ikan gabus sebanyak $60 \%$ dan wortel sebanyak $40 \%$. Mutu organoleptik sosis ikan gabus pada warna sebanyak 11 (36\%) orang yang menyatakan sangat suka pada formula F3 (60\%). Pada formula ini, penggunaan jumlah wortel adalah yang paling banyak digunakan. Wortel yang ditambahkan mempengaruhi warna dari sosis. Sosis tampak lebih cerah dan tidak pucat. Pigmen warna kuning dan oranye dari wortel memberikan berwarna kekuningan pada sosis. Wortel mengandung zat alami yaitu karotenoid yang merupakan pembawa warna kuning, oranye dan merah oranye (Winarno, F.G, 2002).

Keunggulan sosis ikan gabus ini adalah kandungan nilai gizi yang cukup tinggi sehingga bisa menjadi pangan alternatif pencegahan stunting. Sosis ikan gabus ini tidak menggunakan bahan pengawet pada proses pembuatannya sehingga aman untuk dikonsumsi. Penyimpanan sosis ikan gabus ini tidak terlalu lama, sehingga pada penelitian selanjutnya sebaiknya menguji daya simpan dan uji mikrobiologi. Ikan gabus baik dalam pembuatan sosis dikarenakan mengandung protein tinggi, selain itu ikan gabus memilki daging berwarna putih yang sangat baik digunakan dalam pembuatan sosis (Abrori, F, 2003).

\section{KESIMPULAN DAN SARAN}

Analisis kandungan zat gizi protein dan karbohidrat paling tinggi pada formula F1 dan direkomendasikan untuk pencegahan stunting. Pada uji tingkat kesukaan yang paling disukai dari segi rasa dan aroma dan tekstur adalah formula F2 dan untuk warna pada formula F3. Meningkatkan pemberdayaan masyarakat dengan memperkenalkan sosis ikan gabus sebagai pangan alternatif untuk pencegahan stunting. 


\section{DAFTAR PUSTAKA}

Badan Penelitian Pengembangan Kesehatan. (2018). Laporan Riskesdas 2018. Kementerian Kesehatan RI.

F.G, W. (2002). Kimia Pangan dan Gizi. PT. Gramedia Pustaka Utama, Jakarta.

F, A. (2003). Pengaruh proporsi daging ikan dan tepung tapioka terhadap kualitas sosis ikan gabus (Ophiocephalus striatus).

Koapaha, T. (2009). Penggunaan Pati Sagu Modifikasi Fosfat Pada Konsentrasi Yang Berbeda Terhadap Sifat Fisik Kimia Sosis Ikan Patin (Pangasius hypophtalamus). Universitas Brawijaya.

Marimbi, H. (2014). Tumbuh Kembang, Status Gizi dan Imunisasi Dasar Pada Balita. Nuha Medika.
Pratiwi, R. (2017). Hubungan Konsumsi Ikan tehadap Kejadian Stunting pada Anak Usia 2-5 Tahun. Jurnal Kedokteran Diponegoro, 6(1).

Rahayu. (2008). Provitamin A dalam Sosis Fermentasi. Jurnal Pangan Dan Gizi, $35(15)$.

Rosalinda Gibson. (2006). Prinsiples of Nutritional Assessment. Oxford University Press.

Saefuddin. (2015). Essai Hari Ikan Nasional. Radar Cirebon.

Sunita, Almatsier, Susirah Soetardjo, M. S. (2011). Gizi Seimbang Dalam Daur Kehidupan. Gramedia Pustaka Utama Jakarta.

WHO. (2005). Who Child growth standards and the identification of severe acute Malnutrion in infants and children. 